\section{Jakarta Declaration on health promotion into the 21st century}

\section{INTRODUCTION}

Five hundred representatives from 100 countries attended the 4th International Conference on Health Promotion, held in Jakarta, Indonesia, 21-25 July 1997 . The event, which was co-organized by the World Health Organization and the Government of Indonesia, had as its theme "New Players for a New Era: Leading Health Promotion into the 21st Century."

The Jakarta Declaration is the fruit of the Fourth International Conference. The delegates state that health promotion can achieve optimal impact only through coordinated efforts involving all social sectors, nationally and internationally, including in particular the private sector and the population whose health is to be improved. A key unifying theme of the strategies promoted in the Declaration is that investments in successful health promotion yield excellent returns for everyone. The Declaration is reprinted in full below.

\section{THE JAKARTA DECLARATION ON HEALTH PROMOTION INTO THE 21ST CENTURY}

\section{Background}

The 4th International Conference on Health Promotion-New Players for a New Era: Leading Health Promotion into the 21st Century-comes at a critical moment in the development of international strategies for health. It is almost 20 years after the World Health Organization Member States made an ambitious commitment to a global strategy of Health for All, and to the principles of primary health care through the Alma-Ata Declaration. It is 10 years after the 1st International Conference on Health Promotion was held in Ottawa, Canada. That conference resulted in publication of the Ottawa Charter for Health Promotion, which has been a source of guidance and inspiration for health promotion since that time. Subsequent international conferences and meetings have further clarified the relevance and meaning of key strategies in health promotion, including healthy public policy (in Adelaide, Australia, 1988) and supportive environments for health (in Sundsvall, Sweden, 1991).

The 4th International Conference on Health Promotion in Jakarta is the first to be held in a 
developing country and the first to involve the private sector in supporting health promotion. It provides an opportunity to reflect on what has been learned about effective health promotion, to reexamine determinants of health, and to identify the directions and strategies which are required to address the challenges of promoting health in the 21st century.

\section{Health promotion is a valuable investment}

Health is a basic human right and essential for social and economic development.

Increasingly, health promotion is being recognized as an essential element of health development. It is a process of enabling people to increase control over and to improve their health. Health promotion, through investments and actions, acts on the determinants of health to create the greatest health gain for people, to contribute significantly to the reduction of inequities in health, to ensure human rights, and to build social capital. The ultimate goal is to increase health expectancy, and to narrow the gap in health expectancy between countries and groups.

The Jakarta Declaration on health promotion offers a vision and focus for health promotion into the next century. It reflects the firm commitment of participants at the 4th International Conference on Health Promotion to draw upon the widest range of resources to tackle health determinants in the 21st century.

\section{Determinants of health: new challenges}

Prerequisites for health are peace, shelter, education, social security, social relations, food, income, empowerment of women, a stable ecosystem, sustainable resource use, social justice, respect for human rights, and equity. Above all, poverty is the greatest threat to health.

Demographic trends such as urbanization, an increase in the number of older people, and the prevalence of chronic diseases pose new problems in all countries. Other social, behavioral, and biological changes such as increased sedentary behavior, resistance to antibiotics and other commonly available drugs, increased drug abuse, and civil and domestic violence, threaten the health and well-being of hundreds of millions of people.

New and re-emerging infectious diseases and greater recognition of mental health problems require an urgent response. It is vital that health promotion evolve to meet changes in the determinants of health.

Transnational factors also have a significant impact on health. These include the integration of the global economy, financial markets and trade, access to media and communication technology, as well as environmental degradation due to the irresponsible use of resources.

These changes shape values, lifestyles throughout the lifespan, and living conditions across the world. Some have great potential for health, such as the development of communications technology; others, such as international trade in tobacco, have a major negative impact.

\section{Health promotion makes a difference}

Research and case studies from around the world provide convincing evidence that health promotion works. Health promotion strategies can develop and change lifestyles and the social, economic, and environmental conditions which determine health. Health promotion is a practical approach to achieving greater equity in health.

The five Ottawa Charter strategies are essential for success:

- build healthy public policy;

- create supportive environments;

- strengthen community action;

- develop personal skills;

- reorient health services.

There is now clear evidence that:

- Comprehensive approaches to health development are the most effective. Those which use combinations of the five strategies are more effective than single track approaches.

- Settings offer practical opportunities for the implementation of comprehensive strategies. These include megacities, islands, cities, municipalities, and local communities, their markets, schools, workplaces, and health care facilities.

- Participation is essential to sustain efforts. People have to be at the center of health promotion action and decision-making processes for it to be effective.

- Health learning fosters participation. Access to education and information is essential to achieving effective participation and the empowerment of people and communities.

These strategies are core elements of health promotion and are relevant for all countries. 


\section{New responses are needed}

To address emerging threats to health, new forms of action are needed. The challenge for the coming years will be to unlock the potential for health promotion inherent in many sectors of society, among local communities, and within families.

There is a clear need to break through traditional boundaries within government sectors, between government and nongovernment organizations, and between the public and private sector. Cooperation is essential. Specifically, this requires the creation of new partnerships for health on equal ground between the different sectors at all levels of governance in societies.

\section{Priorities for health promotion in the 21st century}

\section{Promote social responsibility for health.}

Decision makers must be firmly committed to social responsibility. Both the public and private sectors should promote health by pursuing policies and practices that:

- avoid harming the health of other individuals;

- protect the environment and ensure sustainable use of resources;

- restrict production and trade in inherently harmful goods and substances such as tobacco and armaments, as well as unhealthy marketing practices;

- safeguard both the citizen in the marketplace and the individual in the workplace;

- include equity-focused health impact assessments as an integral part of policy development.

\section{Increase investments for health development.}

In many countries, current investment in health is inadequate and often ineffective. Increasing investment for health development requires a truly multisectoral approach, including additional resources to education and housing as well as the health sector. Greater investment for health and reorientation of existing investments-both within and between countries-have the potential to significantly advance human development, health, and quality of life.

Investments in health should reflect the needs of certain groups such as women, children, and older people, and indigenous, poor, and marginalized populations.

\section{Consolidate and expand partnerships for health.}

Health promotion requires partnerships for health and social development between the differ- ent sectors at all levels of governance and society. Existing partnerships need to be strengthened and the potential for new partnerships must be explored.

Partnerships offer mutual benefits for health through the sharing of expertise, skills, and resources. Each partnership must be transparent and accountable and be based on agreed ethical principles, mutual understanding, and respect. WHO guidelines should be adhered to.

\section{Increase community capacity and empower the individual.}

Health promotion is carried out by and with people, not on or to people. It improves both the ability of individuals to take action, and the capacity of groups, organizations, or communities to influence the determinants of health.

Improving the capacity of communities for health promotion requires practical education, leadership training, and access to resources. Empowering individuals demands more consistent, reliable access to the decision-making process and the skills and knowledge essential to effect change.

Both traditional communication and the new information media support this process. Social, cultural, and spiritual resources need to be harnessed in innovative ways.

\section{Secure an infrastructure for health promotion.}

To secure an infrastructure for health promotion, new mechanisms of funding it locally, nationally, and globally must be found. Incentives should be developed to influence the actions of governments, nongovernmental organizations, educational institutions, and the private sector to make sure that resource mobilization for health promotion is maximized.

"Settings for health" represent the organizational base of the infrastructure required for health promotion. New health challenges mean that new and diverse networks need to be created to achieve intersectoral collaboration. Such networks should provide mutual assistance within and between countries and facilitate exchange of information on which strategies are effective in which settings.

Training and practice of local leadership skills should be encouraged to support health promotion activities. Documentation of experiences in health promotion through research and project reporting should be enhanced to improve planning, implementation, and evaluation.

All countries should develop the appropriate political, legal, educational, social, and economic environments required to support health promotion. 


\section{Call for action}

Participants are committed to sharing the key messages of the Declaration with their governments, institutions, and communities, to put into practice the actions proposed, and to report back to the 5th International Conference on Health Promotion.

In order to speed progress towards global health promotion, participants endorse the formation of a global health promotion alliance. The goal of this alliance is to advance the action priorities for health promotion expressed in this Declaration.

Priorities for the alliance include:

- raising awareness about the changing determinants of health;

- supporting the development of collaboration and networks for health development;

- mobilization of resources for health promotion;

- accumulating knowledge on best practice;

- enabling shared learning;

- promoting solidarity in action;

- fostering transparency and public accountability in health promotion.

National governments are called to take initiative in fostering and sponsoring networks for health promotion both within and between their countries.

Participants in Jakarta '97 called on WHO to take the lead in building a global health promotion alliance and enabling its Member States to imple- ment the results of the Jakarta Conference. A key part of this role is for $\mathrm{WHO}$ to engage governments, nongovernmental organizations, development banks, UN agencies, interregional bodies, bilateral agencies, the labor movement, and cooperatives, as well as the private sector, in advancing the action priorities for health promotion.

\section{SINOPSIS}

\section{Declaración de Jakarta sobre la promoción de la salud proyectada hacia el siglo XXI}

La 4. ${ }^{a}$ Conferencia Internacional sobre la Promoción de la Salud, que tuvo lugar en Jakarta, Indonesia, del 21 al 25 de julio de 1997 bajo el patrocinio de la OMS y del Gobierno de ese país, ha sentado un antecedente por haber sido la primera de su género en celebrarse en un país en desarrollo y en contar con la participación del sector privado. De forma similar la Declaración de Jakarta, fruto de la Conferencia, plantea conceptos innovadores que se proyectan hacia el futuro siglo. En la Declaración se insta a la comunidad mundial a adoptar determinadas estrategias clave encaminadas a favorecer actividades para la promoción de la salud en el ámbito internacional, reiterándose que dichas actividades rendirán los frutos deseados únicamente si se basan en un común esfuerzo por parte de todos los sectores sociales, especialmente del sector privado y de la propia población que se busca servir. Se subraya, asimismo, que cualquier inversión en la promoción de la salud redundará en abundantes beneficios para todos. 